Research Article

\title{
Effect of Coalbed Methane Well Fracturing on Slope Stability of Open-Pit Coal Mine: A Case Study of Shengli East No. 2 Open-Pit Coal Mine
}

\author{
Qingzhong Zhu, ${ }^{1}$ Bo Wang $\mathbb{D}^{2}{ }^{2}$ Xin Zhao, ${ }^{3}$ Chunchun Liu, ${ }^{1}$ Qing Yu, \\ Liwen Zhang, ${ }^{1}$ Tao Hou, ${ }^{1}$ and Guangjie Sang ${ }^{1}$ \\ ${ }^{1}$ PetroChina Huabei Oilfield Company, Renqiu, Hebei 062552, China \\ ${ }^{2}$ Information Institute of the Ministry of Emergency Management of PRC, Beijing 100029, China \\ ${ }^{3}$ General Prospecting Institute of China National Administration of Coal Geology, Beijing 100039, China \\ ${ }^{4}$ School of Resources and Geosciences, China University of Mining and Technology, Xuzhou, Jiangsu 221116, China
}

Correspondence should be addressed to Bo Wang; wangbo1230038@163.com

Received 15 December 2019; Revised 12 June 2020; Accepted 23 June 2020; Published 16 July 2020

Academic Editor: Jinyang Xu

Copyright (c) 2020 Qingzhong Zhu et al. This is an open access article distributed under the Creative Commons Attribution License, which permits unrestricted use, distribution, and reproduction in any medium, provided the original work is properly cited.

\begin{abstract}
The impact of hydraulic fracture from CBM well fracturing on slope stability of the Shengli East No. 2 open-pit coal mine is analyzed by numerical simulation and limit equilibrium methods. The interference effect of coalbed methane (CBM) well fracturing on slope stability of the open-pit coal mine promotes the coordinated development of CBM, and open-pit coal is discussed before and after coal mining. It shows that nearly horizontal fractures are formed in the coal seam due to CBM well fracturing, of which the dynamic facture length and propping fracture length are $137.2 \mathrm{~m}$ and $105.2 \mathrm{~m}$, respectively. Moreover, the dynamic fracture height is $137.2 \mathrm{~m}$ and propping fracture height is $130.6 \mathrm{~m}$. At the location of perforation, the dynamic fracture width is $0.873 \mathrm{~cm}$ and average propping fracture width is $0.111 \mathrm{~cm}$. The CBM well fracturing barely imposed any effect on slope stability before open-pit coal mining. The maximum vertical displacement at the toe of slope induced by fracturing is $0.293 \mathrm{~mm}$. In situations with and without CBM well fracturing, vertical stress distributions in the toe, top, and interior of slope have no obvious difference. There is some extent of vertical stress increase within the interior of slope, which is merely $0.2 \mathrm{MPa}$ higher than that in the condition of initial in situ stress equilibrium. The presence of hydraulic fractures has little effect on the overall displacement of slope during coal mining; and there is no obvious difference between the slope stability during coal mining and the slope stability impacted by fracturing. According to the results of limit equilibrium method and numerical simulation, the overall slope stability coefficient is 1.5-1.97, which accords with the requirements of the Design Code for Open-Pit Mine of Coal Industry (GB501972015). Therefore, more attentions should be paid to the ways of excavation and sloping during coal mining, avoiding slope instability caused by excavation.
\end{abstract}

\section{Introduction}

As an important way to alleviate the imbalance between the supply and demand of oil and gas and the safe production of coal resources [1-3], CBM development and utilization can also facilitate the optimization of national energy structure and the reduction of greenhouse gas emissions [4]. In order to enhance the exploration and development of CBM resources, the state council issued the Several Opinions on
Speeding up the Extraction and Utilization of Coalbed Methane (Coal Mine Gas) (GBF [2006] No. 47) and the Ministry of Land and Resources issued the Notice on Strengthening the Management on Comprehensive Exploration and Mining of Coal and Coalbed Methane Resources (GTZF [2007] No. 96). They explicitly specify some principles on coal resource development and utilization, including the policies concerning extraction before mining and the concurrence of governance and utilization, the 
adoption of various encouraging and supporting measures to prevent coal mine gas accidents, the efficient utilization of energy resources, and the effective protection of ecological environment. Some scientific issues concerning the coordinated development, orderly connection, positive interaction of CBM and coal resource, and interference effect evaluation between these two kinds of resources during development activities have attracted considerable attention [5]. As the key to the efficient development of CBM, CBM well fracturing may impact the mining of coal mine (underground mine), as the high-strength fracture reformation of CBM wells may induce adverse effects on the coal seam, coal roof and floor, roadway support and layout, mine ventilation, mine waterproofing, comprehensive mechanized mining, etc. [6-9]. Slope stability analysis is a major issue for open-pit mining [10-12]. Some previous studies on slope stability of open-pit coal mines proposed that the alterant or influential factors for stress state and strength property of slope rock mass mainly include lithology, rock mass structure, hydrological effect, weathering, earthquake, natural stress, topographic features, and human activities.

The impact of CBM development on the stability of open-pit coal mines is mainly due to the large number of cracks generated during the fracturing process. Many people have done a lot of research on the influence of cracks on the stability of open-pit coal mine slopes. Wang discovered in the study of Shenglidong No. 2 open-pit coal mine that due to the influence of factors such as structure, local slope steepness, and groundwater, the resulting single-step loose rupture has little effect on open-pit mining in the coal mine [13]; Chen et al. found that the vertical pull of cracks in the open-pit of the open-pit mine has a greater impact on the slope stability, and as the depth of the crack increases, the displacement of the rock mass in the slope also becomes larger [14].

However, researches about the effect of CBM development on slope stability of open-pit coal mines are less, and there is no practical engineering experience for reference. By taking the Shengli East No. 2 open-pit coal mine as a case study, the 3D modeling of fracture geometry caused by the CBM well fracturing was achieved by the Fracpro PT software, and the impact of CBM well fracturing on slope instability before and after open-pit coal mining was simulated by the FLAC3D software. The evaluations of physical and mechanical property changes of the strata after CBM well fracturing and their influence on slope stability of coal mine provide guidance for the collaborative development and utilization of CBM and coal resources in the study area as well as engineering experience for similar projects.

\section{Engineering Geology Background}

Shengli Coal Field is one of the coal basins to the west of the Greater Khingan Range and is located within the Wunite Fault Zone in the east end of Erlian Depression (also known as Erlian Basin Group). There are 9 major and minor normal faults with a strike of about $\mathrm{N} 60^{\circ} \mathrm{E}$ in the study area and the axis of Shengli Syncline passing through the north of central Shengli East No. 2 Open-Pit Mine. A normal fault F68 in the south slope is likely to form a natural lateral boundary for sliding body.

The main coal bearing stratum of Shengli East No. 2 Open-Pit Coal Mine is the 6\# coal seam of Shengli formation of Bayanhua Cluster of the lower Cretaceous System in the Mesozoic group. The 6\# coal seam is characterized by complex architecture with continuous and stable plane distribution and has a buried depth of $30.85-623.00 \mathrm{~m}$, thickness of $1.95-228.30 \mathrm{~m}$, average thickness of $61.43 \mathrm{~m}$, gas content of $1.0-3.6 \mathrm{~m}^{3} / \mathrm{t}$, and permeability of $0.6-6 \mathrm{mD}$ [15-17]. The CBM and coal resources have been exploited in the area. For the target 6\# coal seam, four CBM exploration wells have been completed, two of which have been in the stage of production; in addition, two new wells are about to be drilled. The overall well spacing is about $300 \mathrm{~m} \times 300 \mathrm{~m}$ (Figure 1).

\section{Simulation of Fracture Architecture Induced by CBM Well Fracturing}

Considering the tested mechanical parameters of coal and the floor and roof strata in the study area, a 3D fracturing model was established for fracture architecture after CBM well fracturing in No. 2 Open-Pit Mine in the east of Shengli Coalfield by using the Fracpro PT software, which has commonly been used in hydraulic fracturing design and analysis. Based on the $3 \mathrm{D}$ rock deformation and the 2D flow of fracturing fluid in horizontal and vertical directions along fractures, the continuity equation of fracturing fluid flow in fractures, pressure drop equation, and te mathematical control equations of fracture propagation including fracture width equation and fracture height equation were established [18]. The related fracture simulation parameters are shown in Table 1.

The simulation parameters were determined by the construction parameters of implemented wells, including the coal reservoir depth of about $450 \mathrm{~m}$, the utilization of active hydraulic fracturing fluid with $450 \mathrm{~m}^{3}$ of injection in each segment, the addition of $40 \mathrm{~m}^{3}$ of sand into each section, the construction displacement of $8.1 \mathrm{~m}^{3} / \mathrm{min}$, the fracturing construction duration of $60 \mathrm{~min}$, and the pressure drop measurement for $60 \mathrm{~min}$ after construction.

Figure 2 shows the diagrammatic sketch of fracturing area in the $6 \#$ coal seam. The simulation results show the dominant cracking of horizontal fractures within coal seam during fracturing due to its shallow buried depth. The fracture length, i.e., the dynamic fracture length, is $137.2 \mathrm{~m}$, and the propping fracture length is $105.2 \mathrm{~m}$; the dynamic fracture height is $137.2 \mathrm{~m}$, and the propping fracture height is $130.6 \mathrm{~m}$; the dynamic fracture width, i.e., the uplifted height of the strata in vertical direction, is $0.873 \mathrm{~cm}$ at the location of perforation, and the average propping fracture width is $0.111 \mathrm{~cm}$; the average fracture conductivity is $97.67 \mathrm{mD} \cdot \mathrm{m}$; the dimensionless conductivity is 18.57 . 


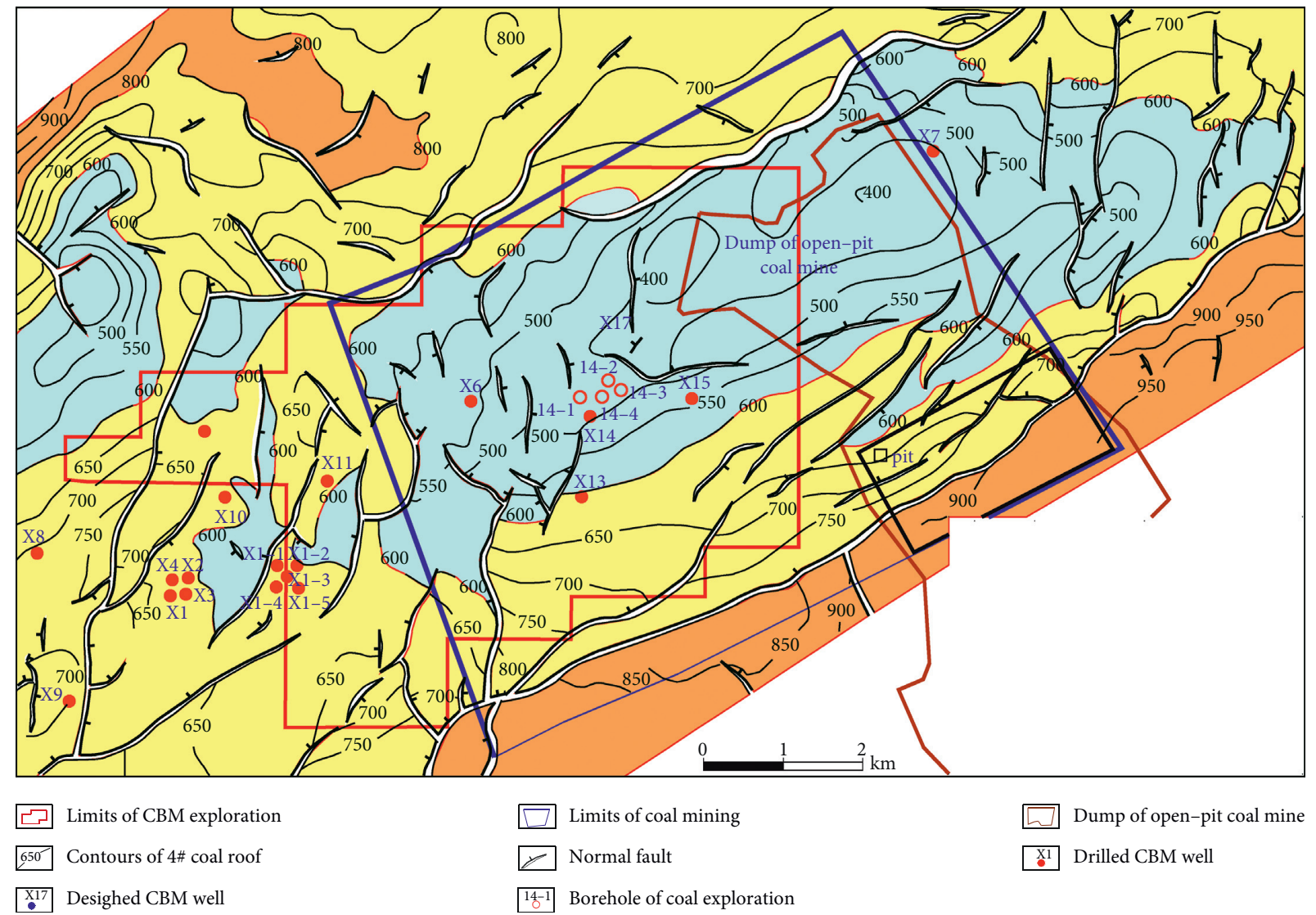

FIgURE 1: Distribution of CBM wells and pit in Shengli East No. 2 Open-Pit Coal Mine.

TABLE 1: The input optimization parameters for Fracpro PT software simulation.

\begin{tabular}{lcc}
\hline Parameter & Value & Unit \\
\hline Reservoir thickness & 50 & $\mathrm{~m}$ \\
Reservoir pressure & 4.69 & $\mathrm{MPa}$ \\
Reservoir pressure gradient & 0.0081 & $\mathrm{MPa} / \mathrm{m}$ \\
Permeability & 0.24 & $\mathrm{mD}$ \\
Formation coefficient & 1.27 & $\mathrm{mD} \cdot \mathrm{m}$ \\
Young's modulus & 3,500 & $\mathrm{MPa}$ \\
Poisson's ratio & 0.3 & - \\
Reservoir temperature & 27.43 & ${ }^{\circ} \mathrm{C}$ \\
\hline
\end{tabular}



FIGURE 2: A sketch map of the section crossing 6\# coal seam with fracturing reformation in Shengli East No. 2 Open-Pit Coal Mine.

\section{Simulation Method, Principle, and Model Establishment for Slope Instability before Open-Pit Coal Mining}

4.1. Principles of FLAC3D Analysis and Computation. The FLAC3D program adopts the fast Lagrangian method in mathematics and obtains the step solutions to all motion equations and constitutive equation of the model based on the explicit difference. The constitutive equation is derived from the basic definition of stress and strain and Hooke's law, while for the motion balance equation, the Cauchy's equation of motion is directly applied, which is derived from Newton's law of motion.

In this paper, the degree and extent of impact imposed by CBM well fracturing were evaluated in views of the damage degree of lithology in CBM development area, the changes in physical and mechanical properties of strata after fracturing, and the mine slope stability. As the fractures for simulation analysis exist in 6\# Coal seam, 6\# coal was taken as a separate group for modeling. Elevation and strata are different for models before and after excavation. To analyze the impact of fractures cracking on slope stability before excavation, the fractures were modeled by the contact surface unit in FLAC3D software; while for slope after coal excavation, the null model in FLAC3D software was used to simulate the slope excavation process and to analyze the impact of fractures on slope stability before and during coal excavation. 


\subsection{Model Establishment}

4.2.1. Analysis of Simulation Results before Coal Mining. According to the stratigraphic conditions of study area, a numerical simulation model was established about the southern slope of the mine pit, in order to evaluate the impact of the nearly horizontal deep fractures induced by CBM exploration well fracturing on slope stability $[19,20]$. The strata were divided into 8 layers through reasonable simplification (Table 2). As the fractures for simulation analysis exist in 6\# coal seam, 6\# coal was taken as a separate group for modeling. For the facilitation of fracturing model establishment, the fractures were divided into 3 layers with elevations of $-200 \mathrm{~m},-220 \mathrm{~m}$, and $-240 \mathrm{~m}$, respectively, and the contact surface unit was adopted for fracturing modeling $[21,22]$.

This slope is $40 \mathrm{~m}$ in height, and the slope angle is $24^{\circ}$. Since the model dimensions would influence the calculation results to a certain extent, the adopted distance from slope toe to the left boundary is $60 \mathrm{~m}$, the distance from slope top to the right boundary is $150 \mathrm{~m}$, and the longitudinal length on slope top is $600 \mathrm{~m}$. The thickness between the slope top and the bottom stratum is $870 \mathrm{~m}$. The boundary conditions were set as a fixed bottom surface, horizontal constraints on both left and right sides, and a free boundary in the upper surface. According to Mohr-Coulomb criterion, the initial stress field was considered as a self-weight stress field, and the computation convergence criterion is that the unbalanced force ratio meets the solution requirements of $10^{-5}$.

The spatial scope of the model is from top to bottom on the ground, and the dimensions are $600 \mathrm{~m} \times 300 \mathrm{~m} \times 870 \mathrm{~m}$ (length $\times$ width $\times$ height) (Figure 3 ). By the adoption of hexahedral and wedge-shaped units within FLAC3D, a total of 1,267,200 units and 1,306,074 nodes were divided.

4.2.2. Simulation of Coal Seam Mining after Fracturing. According to the engineering background, a numerical simulation model was established with reasonable simplification for the southern slope of the mine pit in the study area, so as to reasonably evaluate the impact of the nearly horizontal deep fractures induced by CBM exploration well on slope stability after coal mining. For the selected slope of the pit being mined, the strata were divided into 5 layers through reasonable simplification (Table 3 ). As the fractures for simulation analysis exist in $6 \#$ coal seam, 6\# coal was taken as a separate group for modeling. For the facilitation of fracturing model establishment, the fractures were divided into 3 layers with elevations of $-350 \mathrm{~m},-370 \mathrm{~m}$, and $-390 \mathrm{~m}$, respectively.

For the slope which is $400 \mathrm{~m}$ in height and has an angle of $24^{\circ}$, a numerical model was established based on plane strain status. Since the model dimensions would influence the calculation results to a certain extent, the adopted distance from slope toe to the right boundary is $200 \mathrm{~m}$, the distance from slope toe to the left boundary is $1800 \mathrm{~m}$, the distance from slope top to the left boundary is $900 \mathrm{~m}$, and the longitudinal length on slope top is $300 \mathrm{~m}$. The thickness between the slope top and the bottom stratum is $500 \mathrm{~m}$. The boundary conditions were set as a fixed lower part, horizontal constraints on both left and right sides, and a free boundary in the upper part. According to Mohr-Coulomb criterion, the initial stress field was considered as a selfweight stress field, and the computation convergence criterion is that the unbalanced force ratio meets the solution requirements of $10^{-6}$.

By the adoption of hexahedral and wedge-shaped units within FLAC3D, a total of 16,400 units and 18,942 nodes were divided. The simulation was performed at the following steps: (a) model establishment and initial in situ stress balance; (b) CBM well fracturing; (c) slope excavation and stability calculation. The slope excavation is calculated using the assigned null model (Figure 4).

\section{Simulation of Slope Instability due to CBM Well Fracturing in Open-Pit Coal Mining}

\subsection{Simulation of Slope Instability before Open-Pit Coal Mining}

\subsubsection{Determination of Computation Model Parameters.} Physical and mechanical parameters of overburden rock were determined on the basis of coal-bearing strata distribution. Effect of fracturing on rock and soil mass mainly manifested as structure damage and is expressed as the great decrease in cohesion, which can even drop to zero. Therefore, a residual cohesion value of zero was adopted in this study. Parameters of the rock and soil mass are shown in Table 4.

\subsubsection{Simulation Results}

(1) Recovery of Initial Stress Field. As a major controlling factor for mechanical properties of rock mass, the initial stress field is also one of the important stress sources for rock mass deformation and failure when the ambient condition changes. Since the survey and evaluation area is a mountain with greatly changing terrain slope, obvious difference of stress field variation exists in horizontal and vertical directions. The numerical simulation results show that the vertical stress imposed on strata gradually increases from top to bottom under self-weight stress of the rock and soil mass. The vertical stress reaches a maximum value of about 14.2 $\mathrm{MPa}$ at elevation $-870 \mathrm{~m}$, and its minimum value is near the ground surface, as shown in Figure 5. The rock and soil mass is in tensile state at the slope shoulder, forming a tension zone; the slope toe is in a compression state, forming the maximum shear stress concentrated zone; and the slope surface has a tensile state, which is actually in a two-way stress state as the lateral pressure closes to zero. Therefore, the rock and soil mass is under concentrated stress at slope shoulder and toe, while the stress distribution is relatively scattered on slope surface. The vertical tensile stress value achieves its maximum value, about $3.93 \mathrm{MPa}$, at the slope shoulder. 
TABLE 2: Geometric parameters of the model.

\begin{tabular}{lcc}
\hline Designation of layer & Thickness $(\mathrm{m})$ & Depth $(\mathrm{m})$ \\
\hline Topsoil layer & 40 & 40 \\
Pliocene layer & 50 & 90 \\
Upper coal and rock layer & 100 & 190 \\
Coalbed no. 6 & 60 & 250 \\
Middle coal and rock layer & 150 & 400 \\
Mudstone layer & 90 & 490 \\
Lower coal and rock layer & 260 & 750 \\
Conglomerate layer & 120 & 870 \\
\hline
\end{tabular}

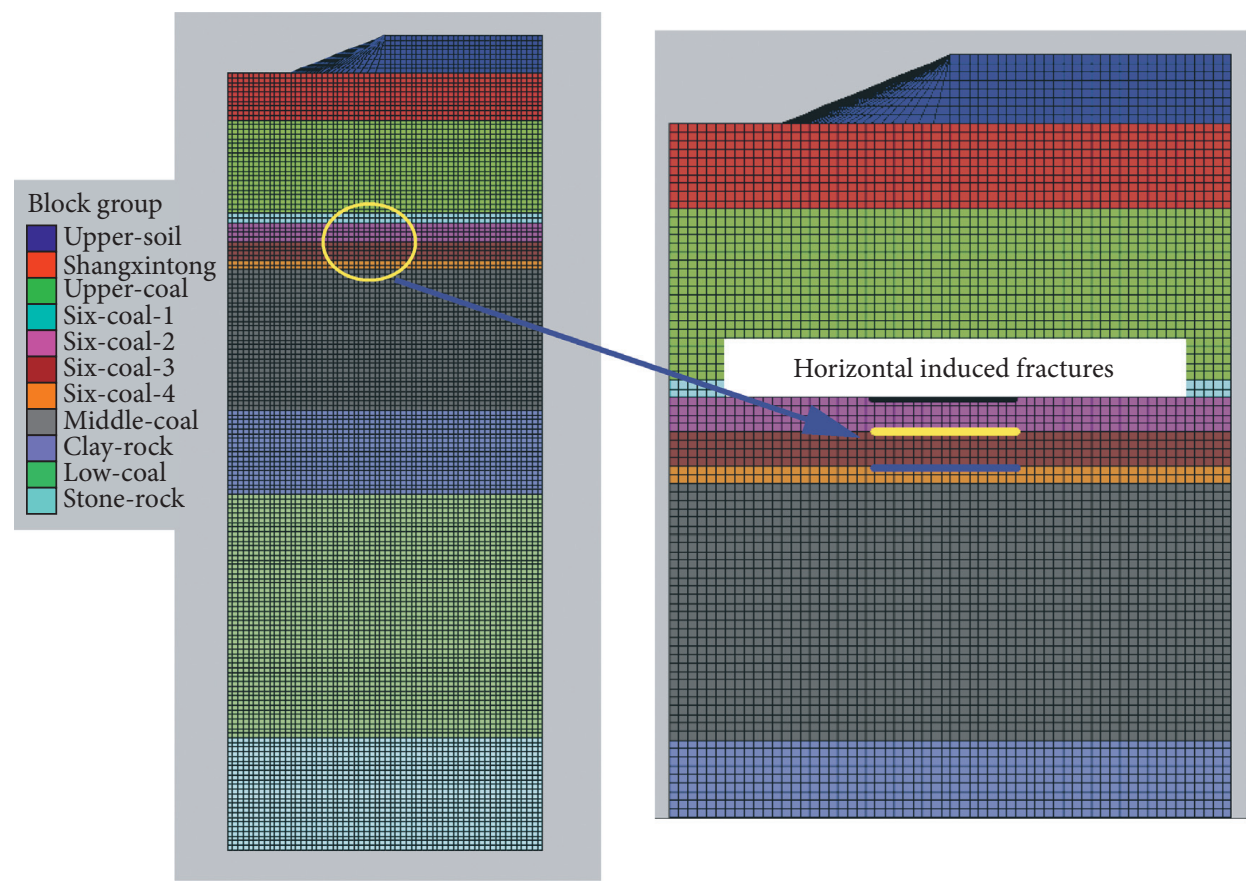

Figure 3: Numerical model of the southern slope of Shengli East No. 2 Open-Pit Coal Mine.

Table 3: Geometric parameters of the model.

\begin{tabular}{lc}
\hline Designation of layer & Thickness $(\mathrm{m})$ \\
\hline Topsoil layer & 90 \\
Coalbed no. 4 & 10 \\
Middle rock layer & 240 \\
Coalbed no. 6 & 60 \\
Bedrock layer & 100 \\
\hline
\end{tabular}

The stress and strain states after the balance of selfweight stress in the numerical model are similar to those of the survey and evaluation area.

(2) Simulation Results of Fracturing. Impact of fractures in 6\# coal seam related to CBM well fracturing on the strata is indicated by a cloud chart of vertical stress for the model after fracturing (Figure 6). The vertical stress in strata mainly concentrates in the vicinity of the three fractures in $6 \#$ coal seam and gradually reduces as it diffuses towards the rock mass interior. Stress distributions of the three fractures are similar and with limited range of influence. The maximum

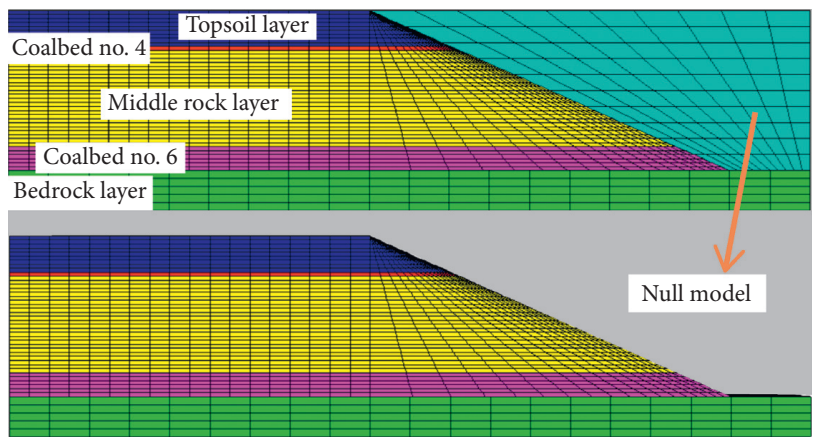

FIgURE 4: Numerical model of the slope after mining on the southern side of the pit.

and minimum vertical stresses near the fractures are 69.30 $\mathrm{MPa}$ and $10 \mathrm{MPa}$, respectively. Stress distribution is gradually scattered towards the overlying rock and soil mass above fractures and eventually becomes consistent with the overall stress field of rock and soil mass. Vertical stress state of other strata has no obvious alteration. As shown in the 
TABLE 4: Material parameters of the geological model.

\begin{tabular}{|c|c|c|c|c|c|c|}
\hline Type of layer & $\begin{array}{l}\text { Bulk density } \\
\left(\mathrm{kg} / \mathrm{m}^{3}\right)\end{array}$ & $\begin{array}{l}\text { Bulk modulus } \\
\qquad(\mathrm{MPa})\end{array}$ & $\begin{array}{l}\text { Shear modulus } \\
\qquad(\mathrm{MPa})\end{array}$ & $\begin{array}{l}\text { Tensile strength } \\
(\mathrm{MPa})\end{array}$ & $\begin{array}{l}\text { Cohesion } \\
(\mathrm{MPa})\end{array}$ & $\begin{array}{c}\text { Friction angle } \\
\left({ }^{\circ}\right)\end{array}$ \\
\hline Topsoil layer & 1,800 & 12.5 & 5.8 & 1 & 0.13 & 18 \\
\hline Pliocene layer & 2,300 & 1,390 & 1,040 & 1.8 & 2.3 & 24 \\
\hline $\begin{array}{l}\text { Upper coal and rock } \\
\text { layer }\end{array}$ & 1,500 & 4,780 & 3,740 & 8.7 & 1.32 & 27 \\
\hline Coalbed no. 6 & 1,500 & 4,780 & 3,740 & 8.7 & 1.32 & 27 \\
\hline $\begin{array}{l}\text { Middle coal and rock } \\
\text { layer }\end{array}$ & 1,500 & 4,780 & 3,740 & 8.7 & 1.32 & 27 \\
\hline Mudstone layer & 2,200 & 1,390 & 1,000 & 1.5 & 2.0 & 21 \\
\hline $\begin{array}{l}\text { Lower coal and rock } \\
\text { layer }\end{array}$ & 1,500 & 4,780 & 3,740 & 8.7 & 1.32 & 27 \\
\hline Conglomerate layer & 2,600 & 7,550 & 6,140 & 1.87 & 8.56 & 37 \\
\hline Coal mass fracture layer & 0 & 0 & 0 & 0 & 0 & 15 \\
\hline
\end{tabular}
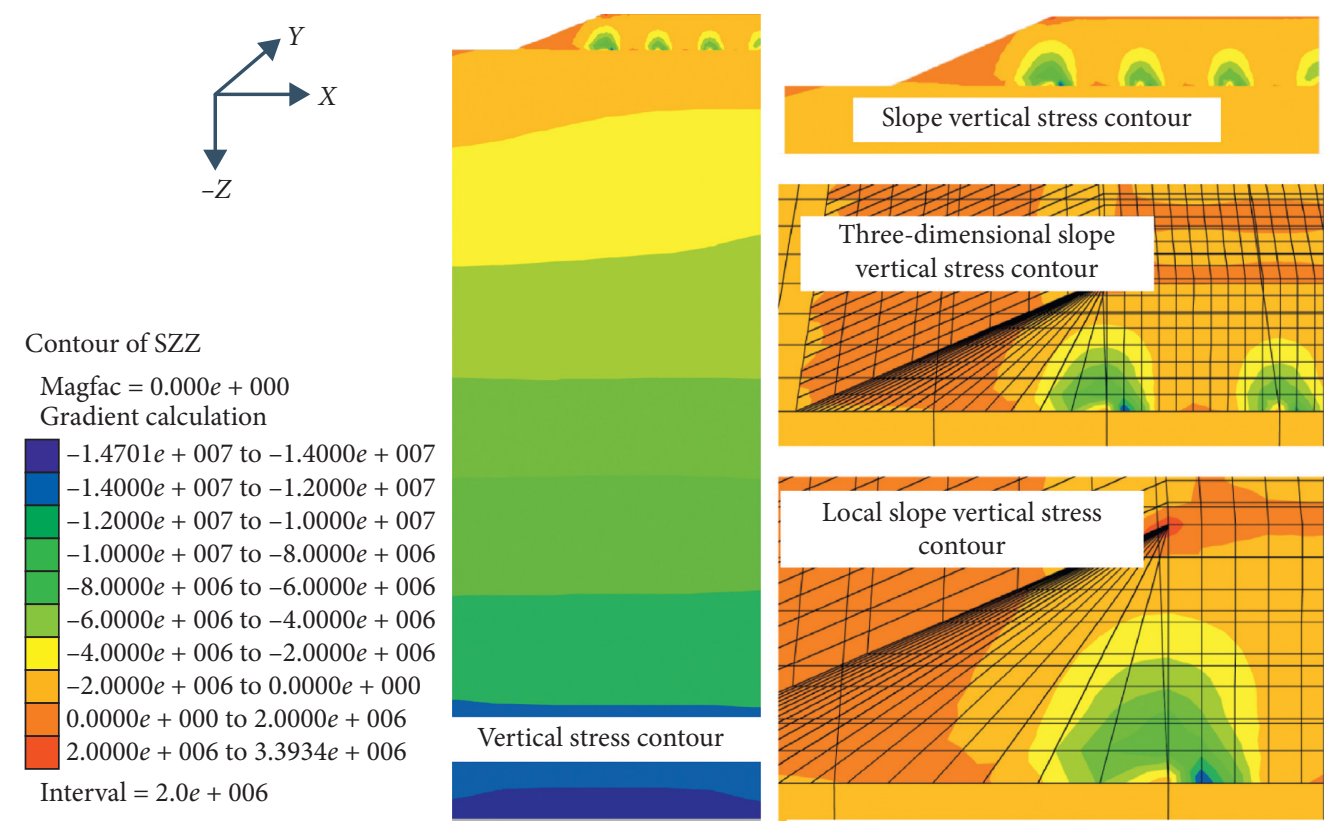

FIGURE 5: Cloud chart of the overall vertical stress after initial in situ stress balance.

cloud chart of vertical displacement for the model after fracturing (Figure 7), vertical displacement occurs on the rock mass above hydraulic fractures, which reaches a maximum value of $0.5 \mathrm{~mm}$. The overall displacement of rock mass above fractures is larger than that of the lower rock mass, which acquires a maximum vertical displacement of $0.250 \mathrm{~mm}$. For the hydraulic fractures formed in coal seam, the vertical displacement gradually decreases from center to both sides and the maximum vertical displacement in central part is $2.21 \mathrm{~mm}$. Furthermore, for the three fractures, the vertical displacement of a fracture increases with the decrease of its spatial location.

The vertical stress states within the slope toe, slope top, and interior of slope after fracturing are shown in cloud chart of vertical stress (Figure 8). It is clear that the vertical stress distribution within the interior of slope was not influenced by the nearly horizontal deep fractures induced by CBM exploration well fracturing. Compared with the initial stress field distribution, the vertical stress field distribution almost has no alteration as the maximum shear stress concentrated zone related to self-weight of rock and soil mass is still at slope toe. The toe and top of slope are still in stress concentration state, while the stress distribution is relatively scattered on slope surface. The maximum vertical tensile stress value, about $3.93 \mathrm{MPa}$, occurs on slope shoulder. However, conspicuous difference of stress field exists at the same location within the interior of slope, where the vertical stress value of about $14.4 \mathrm{MPa}$ is $0.2 \mathrm{MPa}$ higher than that in the initial stress field. From the cloud chart of vertical displacement for slope after fracturing (Figure 9), vertical displacement of rock and soil mass decreases gradually from slope top to slope toe. The maximum vertical 


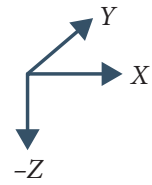

Contour of SZZ

Magfac $=0.000 e+000$

Gradient calculation

$-6.9269 e+007$ to $-6.0000 e+007$

$-6.0000 e+007$ to $-5.0000 e+007$

$-5.0000 e+007$ to $-4.0000 e+007$

$-4.0000 e+007$ to $-3.0000 e+007$

$-3.0000 e+007$ to $-2.0000 e+007$

$-2.0000 e+007$ to $-1.0000 e+007$

$-1.0000 e+007$ to $0.0000 e+000$

$0.0000 e+000$ to $3.4817 e+006$

Interval $=1.0 e+007$

FIGURE 6: Cloud chart of vertical stress for the model after fracturing.

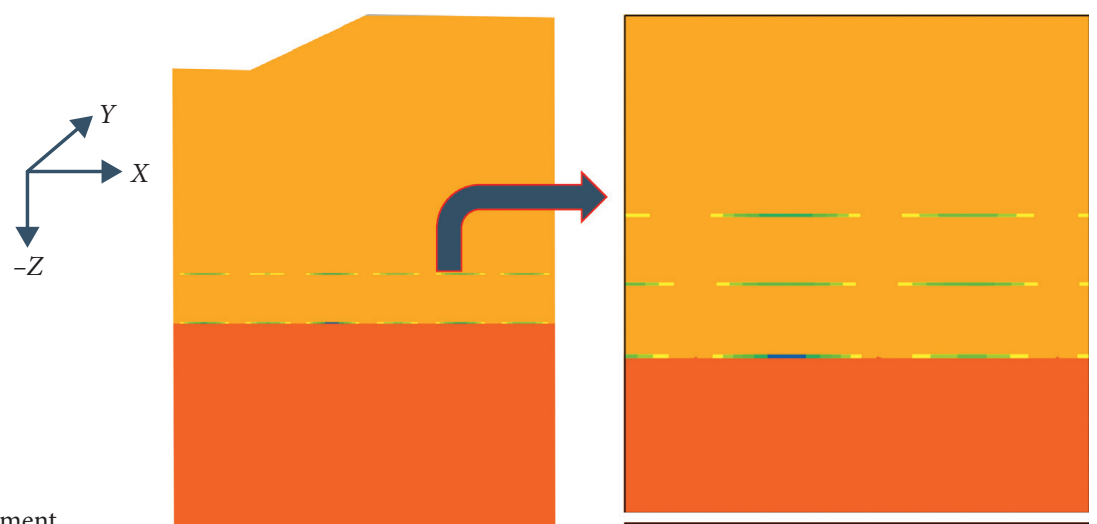

Contour of Z-displacement

Magfac $=0.000 e+000$

$-2.2066 e-003$ to $-2.0000 e-003$

$-2.0000 e-003$ to $-1.7500 e-003$

$-1.7500 e-003$ to $-1.5000 e-003$

$-1.5000 e-003$ to $-1.2500 e-003$

$-1.2500 e-003$ to $-1.0000 e-003$

$-1.0000 e-003$ to $-7.5000 e-004$

$-7.5000 e-004$ to $-5.0000 e-004$

$-5.0000 e-004$ to $-2.5000 e-004$

$-2.5000 e-004$ to $-2.2199 e-005$

Interval $=2.5 e-004$

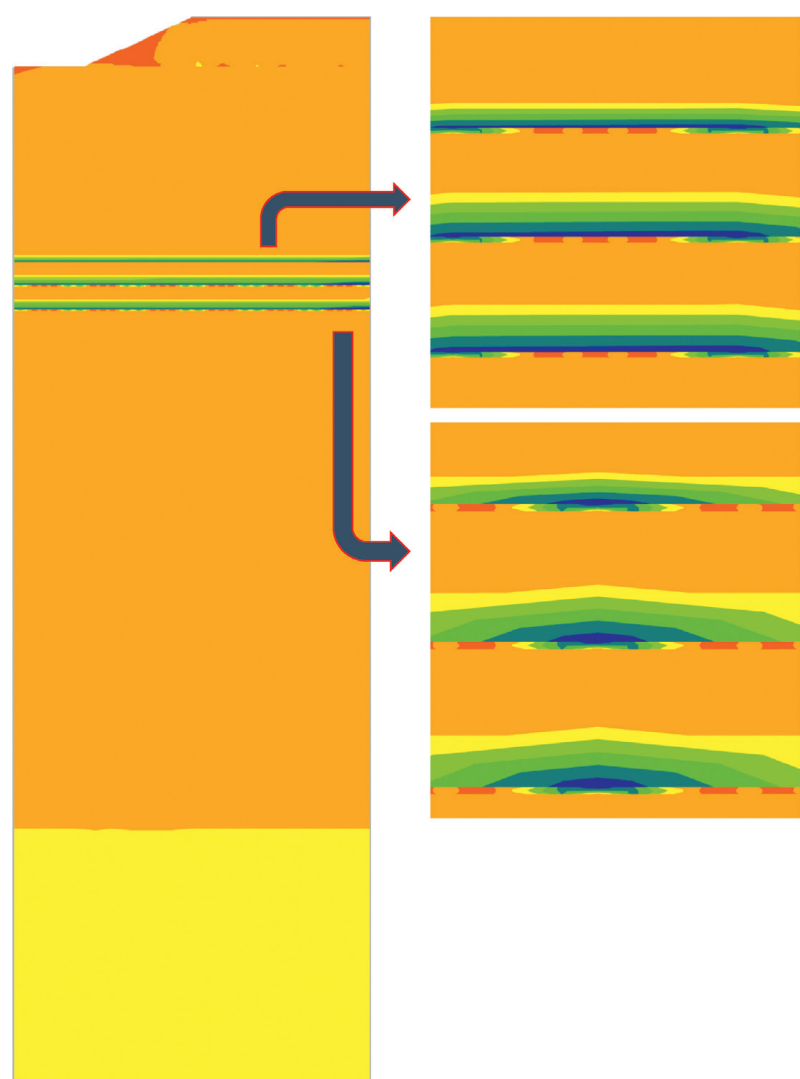






FIgURE 8: Cloud chart of vertical stress after fracturing.

displacement is $0.294 \mathrm{~mm}$ at slope top and the minimum vertical displacement is $0.275 \mathrm{~mm}$ at slope toe, and the difference between them is about $0.018 \mathrm{~mm}$.

\subsection{Simulation of Slope Instability during Open-Pit Coal Mining}

5.2.1. Determination of Parameters for Computation Model. Physical and mechanical parameters of overburden rock were selected according to the synthetic columnar of coal seam within the proposed line site. Effect of fracturing on rock and soil mass mainly manifested as structure damage and is expressed as the great decrease of cohesion, which can even drop to zero. Therefore, a residual cohesion value of zero was adopted in this study. Parameters of the rock and soil mass are shown in Table 5.

\subsubsection{Simulation Results Analysis}

(1) Simulation Results of Slope with Conventional Excavation. After conventional excavation of slope, a large settlement, with the maximum value of $4.146 \mathrm{~m}$, formed on the surface, while no obvious settlement is observed in other parts (Figure 10). Horizontal displacement mainly occurs at the slope top and its vicinity with a maximum value of
$0.45244 \mathrm{~m}$ (Figure 11) and is small in other parts, indicating a moving trend towards slope external. Displacement is small at the junction of slope top and slope surface; horizontal displacement extends towards the free surface at the front edge of slope top and the upper part of slope surface, and displacement is expressed as a circle distribution with the maximum value in the center where slope stability would be affected and collapse tends to occur.

(2) Simulation Results of Slope Excavation in the Presence of CBM Well Fracturing. The CBM development is a desorption-diffusion-seepage process, and continuous dewatering and depressurization are the main features of CBM production. During the continuous dewatering and depressurization process of coal seam, fluid in the open hole is continuously discharged, which results in the continuous pressure decrease therein and a constant release of stratum stress towards the open hole; as a result, the in situ stress within coal seam redistributes constantly and thus the internal architecture of coal seam changes. In the process of coal reservoir dewatering and depressurization, the effective stress on coal increases due to the decrease of fluid pressure as the fluid is discharged from reservoir pores and fractures; consequently, the fractures within coal seam is subject to compressional deformation, and the coal matrix expands so that the matrix particles contact and extrude with each other 


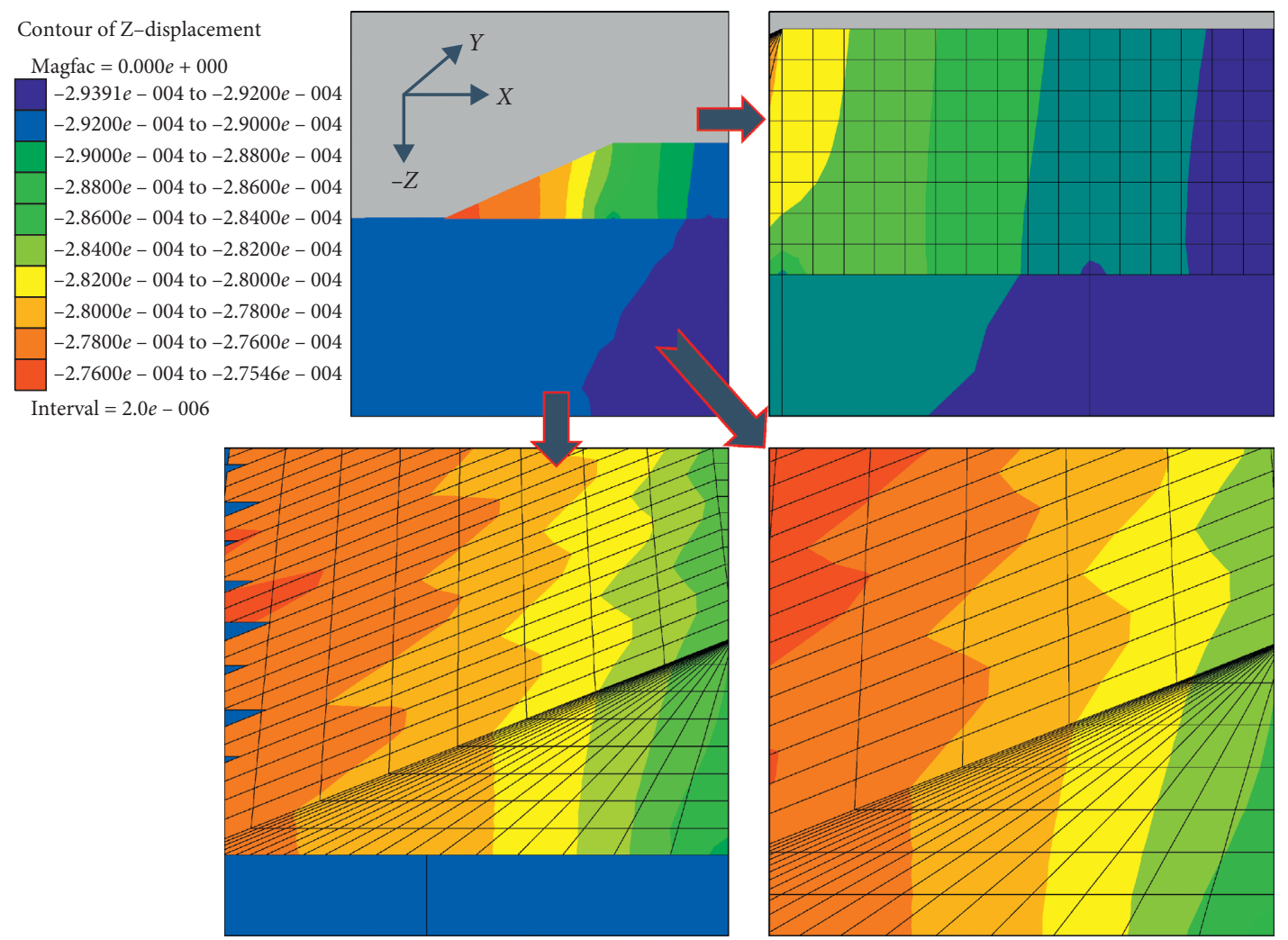

FIgURE 9: Cloud chart of vertical displacement for the slope after fracturing.

TABle 5: Material parameters of the geological model.

\begin{tabular}{|c|c|c|c|c|c|c|}
\hline Type of layer & $\begin{array}{c}\text { Bulk density } \\
\left(\mathrm{kg} / \mathrm{m}^{3}\right)\end{array}$ & $\begin{array}{c}\text { Bulk modulus } \\
(\mathrm{MPa})\end{array}$ & $\begin{array}{c}\text { Shear modulus } \\
(\mathrm{MPa})\end{array}$ & $\begin{array}{c}\text { Tensile strength } \\
(\mathrm{MPa})\end{array}$ & $\begin{array}{c}\text { Cohesion } \\
(\mathrm{MPa})\end{array}$ & Friction angle $\left({ }^{\circ}\right)$ \\
\hline Topsoil layer & 1,800 & 12.5 & 5.8 & 1 & 0.13 & 18 \\
\hline Coalbed no. 4 & 1,500 & 4,780 & 3,740 & 8.7 & 1.32 & 27 \\
\hline Middle rock layer & 2,300 & 1,390 & 1,040 & 1.8 & 2.3 & 24 \\
\hline Coalbed no. 6 & 1,500 & 4,780 & 3,740 & 8.7 & 1.32 & 27 \\
\hline $\begin{array}{l}\text { Conglomerate } \\
\text { layer }\end{array}$ & 2,600 & 7,550 & 6,140 & 1.87 & 8.56 & 37 \\
\hline Coal mass fracture & 0 & 0 & 0 & 0 & 0 & 0 \\
\hline
\end{tabular}

through their surfaces, so the porosity of coal reservoir decreases. After completion of CBM production, hydraulic fractures will exist within the whole slope.

The simulation results show that no difference occurs in the vertical displacement of slope with hydraulic fractures compared with that of the conventional slope. A large settlement, with the maximum value of $4.146 \mathrm{~m}$, formed on the surface, while no obvious settlement is observed in other parts (Figure 12). Moreover, there is substantially no difference of horizontal displacement variation compared with that within the conventional slope without hydraulic fractures. The horizontal displacement mainly concentrates around the slope top, with a maximum value of $0.45235 \mathrm{~m}$ (Figure 13). Large displacement occurs on the front edge of slope top and the central part of upper slope surface, indicating a tendency for collapsing in these locations. More attentions should be paid to the slope top in slope angle design and slope protection as displacement variation of this part is more sensitive during excavation.

The impact of hydraulic fractures induced by CBM well fracturing on the overall displacement variation of slope is small, and the horizontal displacement difference with the conventional slope is merely $0.09 \mathrm{~mm}$. Therefore, there is no obvious difference between the slope stability during coal mining and the slope stability impacted by fracturing; besides, attention should be paid to the ways of excavation and sloping during coal mining, avoiding slope instability caused by excavation.

\section{Evaluation of Slope Stability in the Presence of Hydraulic Fractures}

Considering the fact that the formed pit slopes during openpit coal mining are classified as large-scale slope and the 


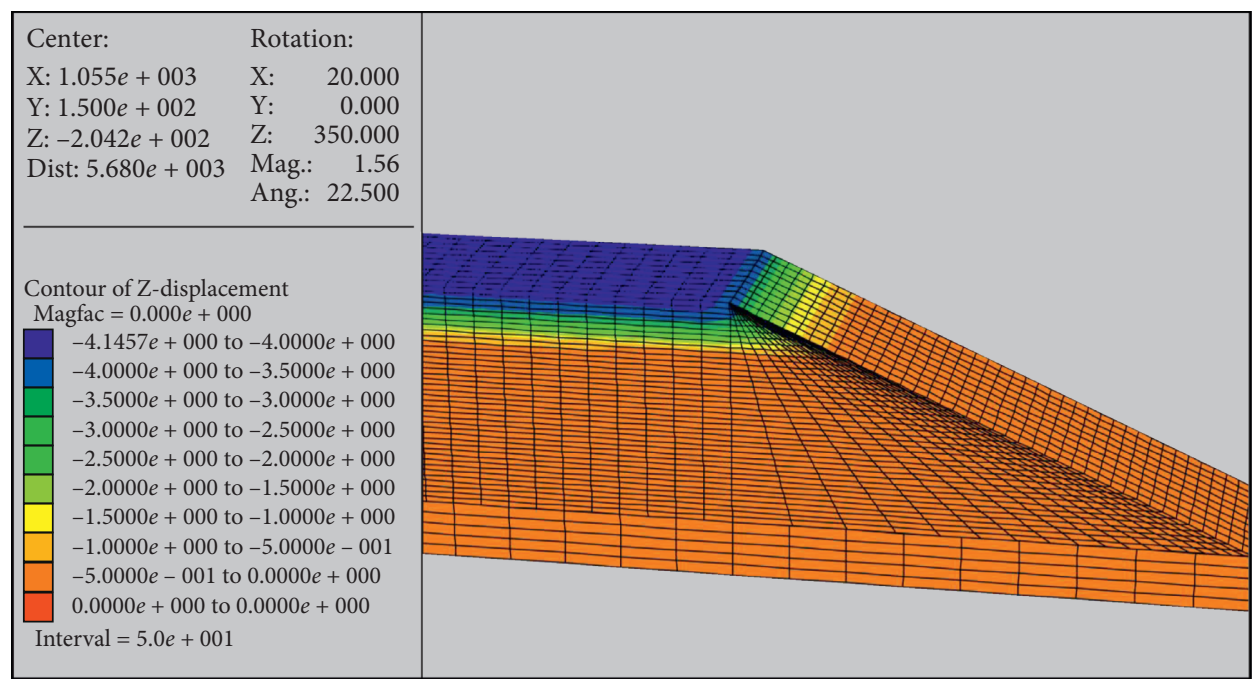

Figure 10: Vertical displacement of a slope after conventional excavation.

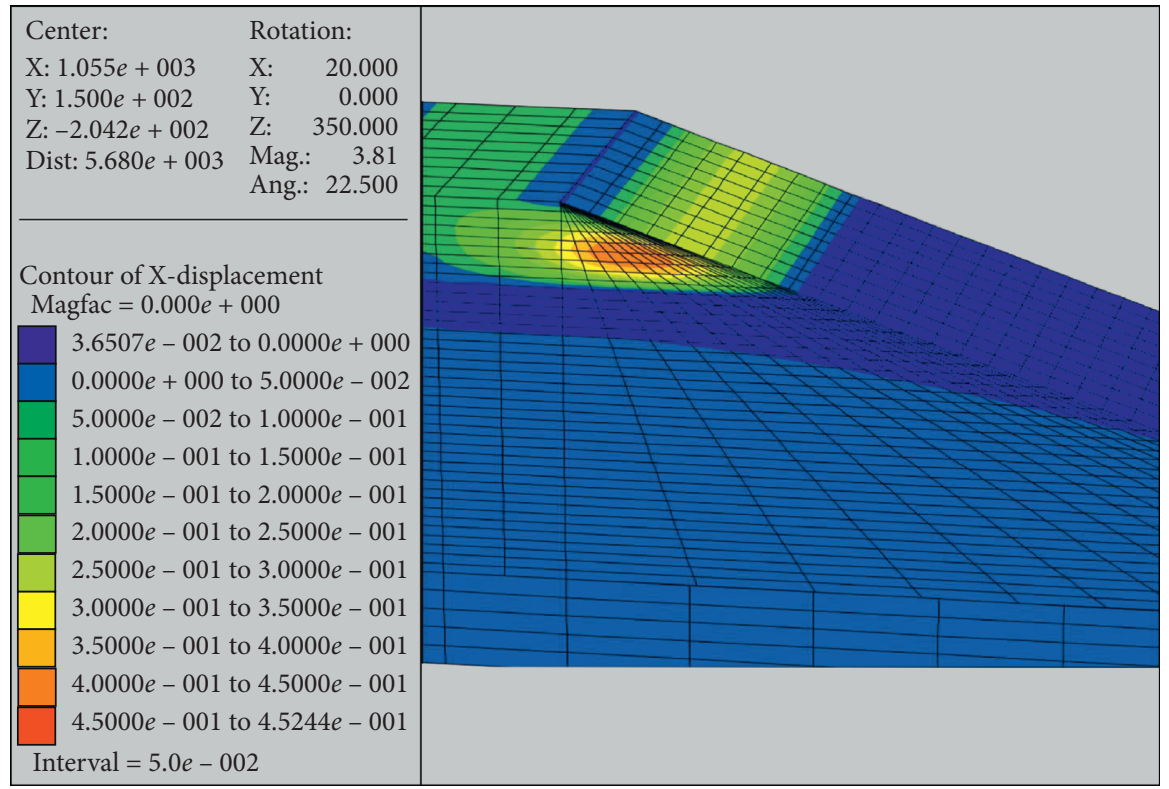

FIGURE 11: Horizontal displacement of a slope after conventional excavation.

existence of hydraulic fractures induced by CBM well fracturing, it is necessary to evaluate the slope stability during excavation. In this paper, stability evaluation is conducted with the numerical method and limit equilibrium method. Slope stability in the presence of hydraulic fractures can be evaluated by FLAC3D software, and the stability coefficient can be calculated with the limit equilibrium method. By comparing the results obtained from both methods, the accuracy of slope stability evaluation in the presence of hydraulic fractures can be improved.

6.1. Numerical Simulation of Slope Stability. Slope stability is evaluated based on the numerical model of the slope after pit mining. The overall stability coefficients calculated by numerical simulation software are 1.93 and 1.89 for the slope excavations into 4\# coal seam and 6\# coal seam, respectively. The calculation results are shown in Figure 14.

The minimum slope stability coefficient of 1.89 conforms to the Design Criterion for Open-Pit Mine of Coal Industry GB50197-2015 (Table 6), in which the safety stability coefficient is specified to be greater than 1.5.

\subsection{Theoretical Calculation of Slope Stability by Limit Equilibrium Method}

6.2.1. Principle of Limit Equilibrium Method. Principles of the limit equilibrium analysis method for rigid bodies include the exclusive consideration of limit equilibrium state of failure surface (sliding surface), regardless of the deformation and failure of sliding rock and soil mass, the control 


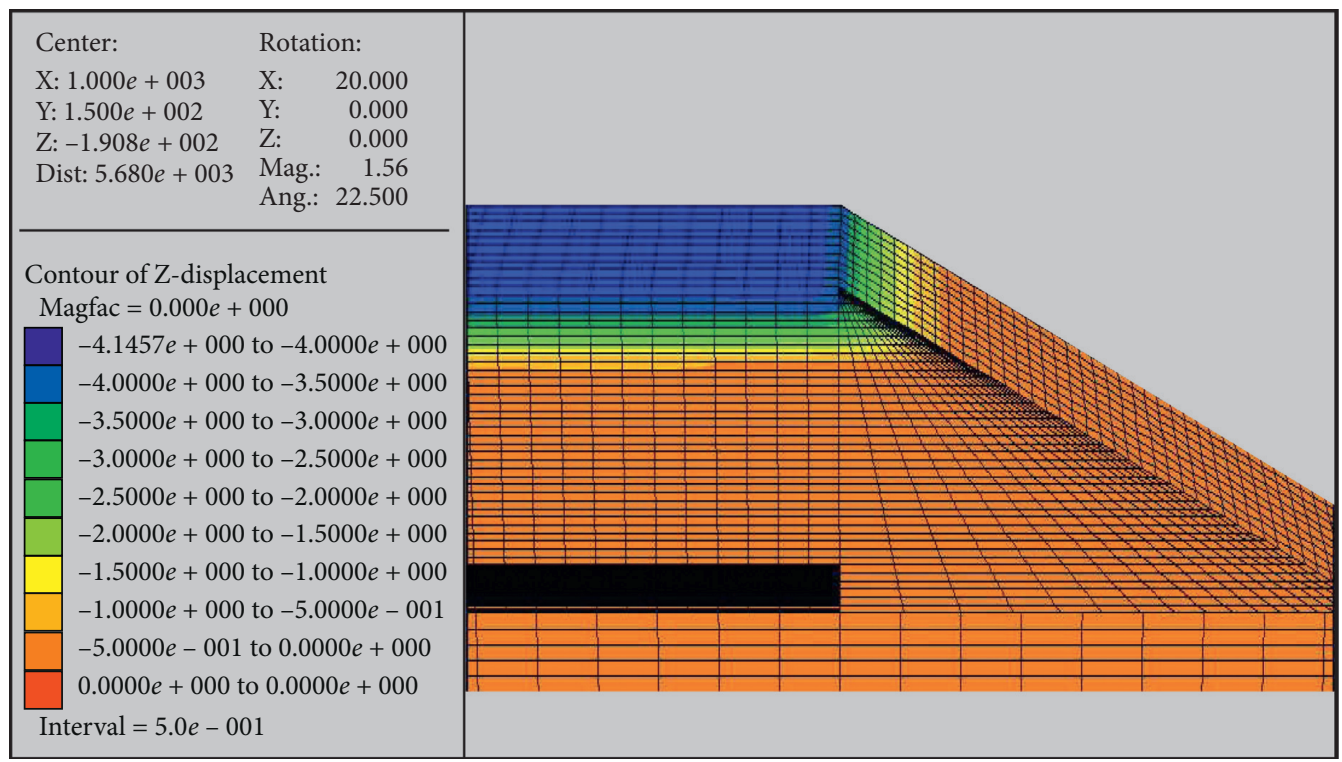

Figure 12: Vertical displacement after slope excavation in the presence of hydraulic fractures.

of cohesion and friction angle ( $c, \varphi$ value) on strength of failure surface (sliding surface) whose failure follows the Coulomb criterion, and the simplification of slope failure onto a plane with normal stress and shear stress acting on the sliding surface. Based on the basic principles of limit equilibrium of rigid body, the following equilibrium equation is obtained:

$$
K_{s}=\frac{\text { antisliding force }}{\text { sliding force }}=\frac{R}{E},
$$

where $K_{s}$ is the landslide stability coefficient. As a kind of calculation theory, the limit equilibrium method for rigid bodies involves many calculation methods, such as the Sweden slice method, Bishop slice method, and transfer coefficient method (or residual thrust method) which have been widely used in China's engineering practices. In the transfer coefficient method, the sliding surface is assumed to be a broken line and is divided into stripes (Figure 15). The angles between individual blocks and the horizontal surface are $\alpha_{1}, \alpha_{2}, \ldots, \alpha_{n}$ from the rear edge of the sliding slope to its front edge. It is assumed that the pushing force $E_{i}$ of block $i$ is parallel to the sliding surface of this block $(i=1,2, \ldots, n)$, and then for each block, the $E_{i}$ can be calculated as

$$
\begin{aligned}
E_{i}= & W_{i}^{\prime} \sin \alpha_{i}+\left(P W_{i-1}-P W_{i}\right) \cos \alpha_{i} \\
& -\frac{1}{K s}\left\{\operatorname{tg} \varphi_{i} \cdot\left[W_{i}^{\prime} \cos \alpha_{i}-U_{i}-\left(P W_{i-1}-P W_{i}\right) \sin \alpha_{i}\right]+C_{i} L_{i}\right\} \\
& +E_{i-1}\left[\cos \left(\alpha_{i-1}-\alpha_{i}\right)-\frac{\operatorname{tg} \varphi_{i}}{K s} \sin \left(\alpha_{i-1}-\alpha_{i}\right)\right],
\end{aligned}
$$

where $\quad R_{i}=\operatorname{tg} \varphi_{i} \cdot\left[W_{i}^{\prime} \cos \alpha_{i}-U_{i}-\left(P W_{i-1}-P W_{i}\right) \sin \right.$ $\left.\alpha_{i}\right]+C_{i} L_{i}, R_{i}$ is the antisliding force of the block $i, \mathrm{MPa} ; E_{i}$ is the pushing force of the block $i, \mathrm{MPa} ; E_{i-1}$ is the pushing force of the block $i-1, \mathrm{MPa} ; W_{i}$ is the gravity of the block $i, \mathrm{MPa} ; L_{i}$ is the bottom surface length of the block $i, \mathrm{~m} ; P W_{i}$ is the lateral pressure of block $i$ imposed by groundwater, $\mathrm{MPa}$; $U_{i}$ is the uplift pressure of block $i$ imposed by groundwater, $\mathrm{MPa} ; C_{i}$ is the effective cohesion of bottom surface of block $i, \mathrm{kPa} ; \varphi_{i}$ is the internal friction angle of bottom surface of block $i, \mathrm{kPa}$; and $\alpha_{i}$ is the the angle between the bottom of block $i$ and the horizontal plane, .

6.2.2. Slope Conditions. According to the engineering background, strata in slope of the pit after mining are reasonably simplified and divided into 4 layers. The designation and thickness of each layer are shown in Table 7.The slope has a height of $400 \mathrm{~m}$ and an angle of $24^{\circ}$, with the soft layer distributing within depths of $108 \mathrm{~m} \sim 119 \mathrm{~m}$. A normal fault F68 developed in the slope. Rocks within fault zone were extremely broken and have poor strength index. Therefore, the fault is likely to form a natural lateral boundary for sliding body. When 6\# coal seam is being mined, it can form a potential slip surface with fault F68 and the weak layer under $4 \#$ coal seam; when $4 \#$ coal seam is being mined, it can also form a potential slip surface with the fault. The hydraulic fractures induced by CBM well fracturing can be considered as joint fractures in the stratum. During mining of 6\# coal seam, the fractures can also be potential sliding surfaces. The sliding surface was determined to be in the center of $6 \#$ coal seam. Slope stability can be evaluated with consideration of the most unfavorable state of fracture connection.

6.2.3. Calculation Results and Analysis. For the evaluation of rock and soil mass stability, the sliding surfaces with various shapes should be assumed firstly; then the ultimate resistance should be determined by the sliding surfaces; and the stability coefficient can be obtained afterwards. In the 


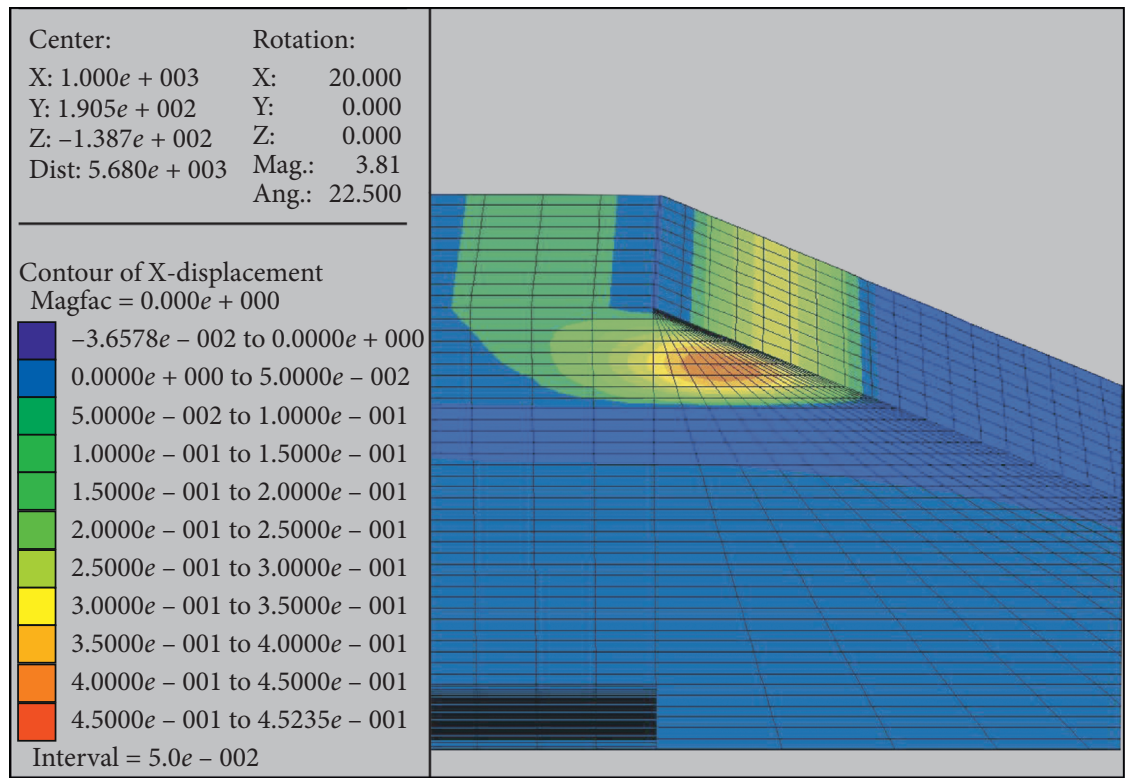

FiguRE 13: Horizontal displacement after slope excavation in the presence of hydraulic fractures.

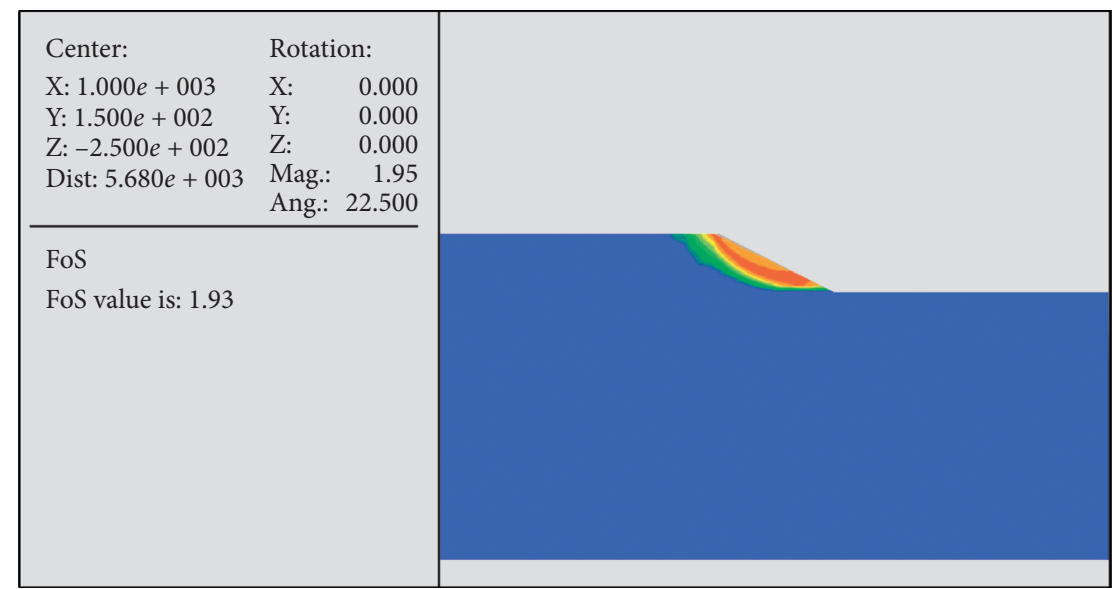

(a)

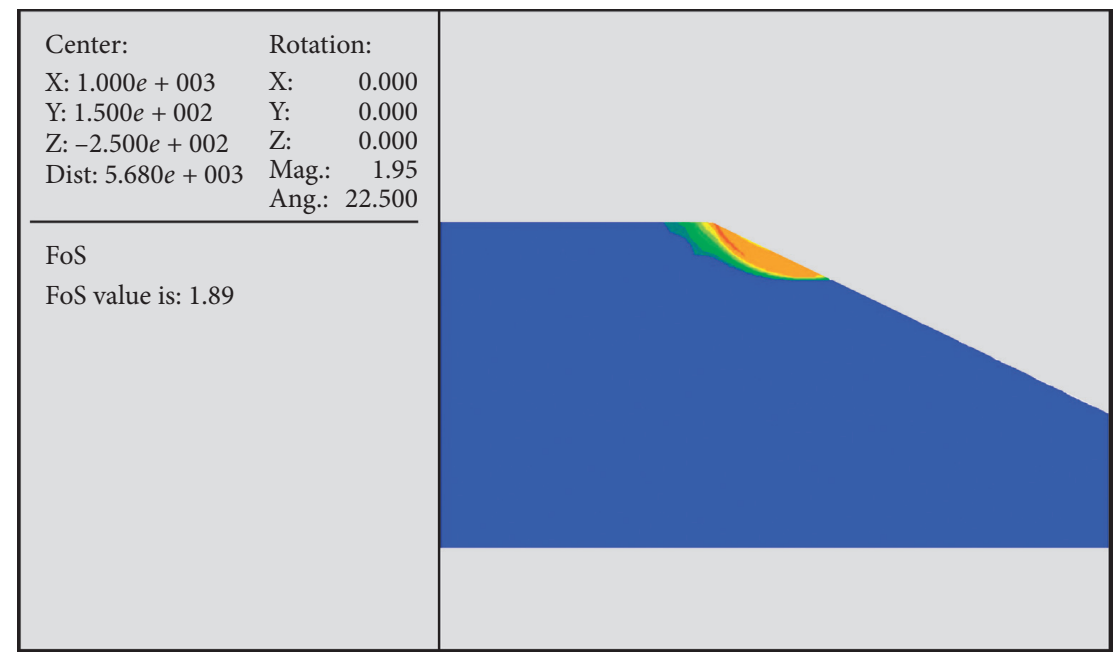

(b)

FIGURE 14: Numerical simulation results of slope stability evaluation. Stability evaluation of slope with slope excavation into (a) $4 \#$ coal seam and (b) 6\# coal seam. 
TABLE 6: Requirements of slope stability coefficients.

Type of slope

Service years

Stability coefficient

Slope on which there are particularly important buildings or

whose sliding may cause major loss of life or property

Final slope of the mining site

$>20$

$>20$

$<10$

Nonworking slope

Working slope

Slope of external dump

Slope of internal dump
$10-20$

$>20$

Temporary

$>20$

$<10$

$\geq 10$
$1.3-1.5$

$1.1-1.2$

$1.2-1.3$

$1.3-1.5$

$1.05-1.2$

$1.2-1.5$

1.2

1.3

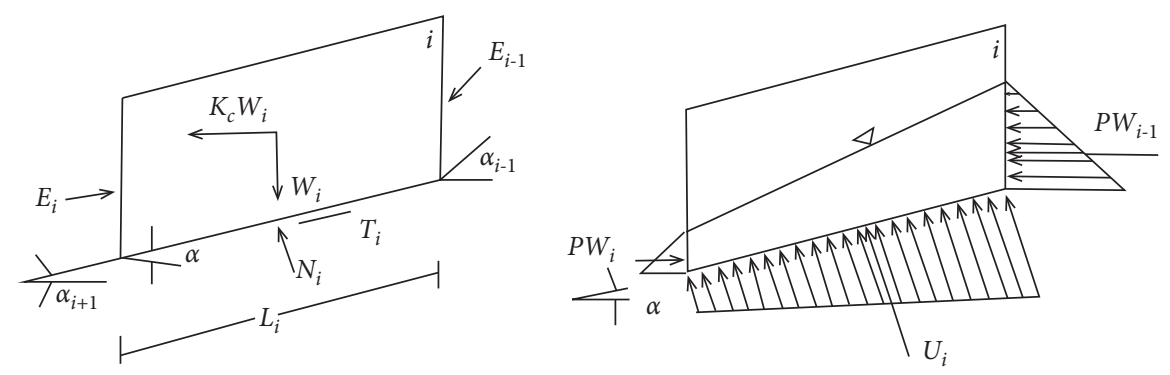

FIgURE 15: Sketch maps of force imposed on the slide block $i$.

TABLE 7: Strata division for slope stability calculation and physical and mechanical parameters for sliding slope stability calculation.

\begin{tabular}{|c|c|c|c|c|}
\hline Designation of layer & Thickness (m) & Natural bulk density $\left(\mathrm{kg} / \mathrm{m}^{3}\right)$ & Cohesion (MPa) & Friction angle $\left({ }^{\circ}\right)$ \\
\hline Topsoil layer & 100 & 2,000 & 0.13 & 18 \\
\hline Coalbed no. 4 & 10 & 1,500 & 1.32 & 27 \\
\hline Soft layer & 10 & 1,800 & 0.13 & 18 \\
\hline Middle rock layer & 220 & 2,300 & 2.0 & 21 \\
\hline 6\# coal seam & 60 & 1,500 & 1.32 & 27 \\
\hline Bedrock layer & 100 & 2,600 & 8.56 & 37 \\
\hline
\end{tabular}
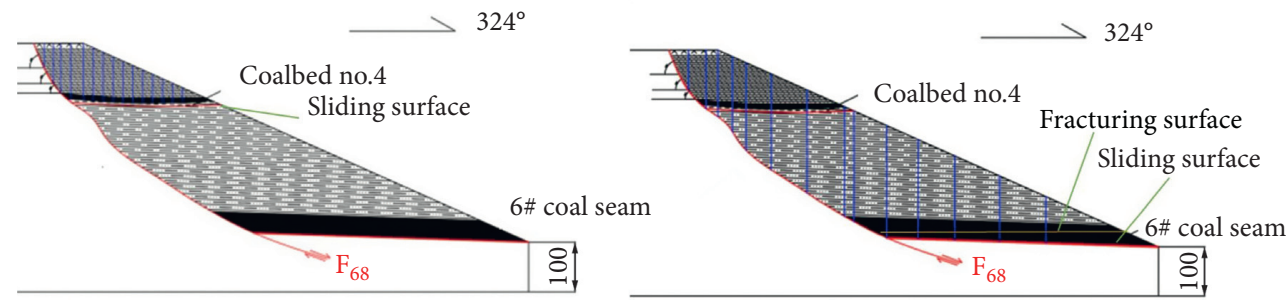

FIGURE 16: Sketch maps of stability calculation of all slide blocks.

stability calculation, the measured longitudinal section was taken as the calculation section, and local calculations were carried out for the upper sliding slope (case 1: sliding surface of soft layer) and the lower sliding slope (case 2a: with fracturing surface of $6 \#$ coal seam, and case $2 \mathrm{~b}$ : with sliding surface of $6 \#$ coal seam, whose parameters are the same) as shown in Figure 16.

Based on the geological mapping of measured profile, drilling, trenching, and aboveground works, together with the structural analysis of sliding slope bodies, the issue of sliding slope stability is simplified into calculations within a
2D space. With a comprehensive consideration of the physical and mechanical property differences between the sliding body and weak zone in longitudinal and horizontal directions, subdivision is conducted in combination of surface slope shape and potential sliding surface variation. Calculation was conducted with the transfer coefficient method. The calculation process is shown in Tables $8-10$, and the calculation results are shown in Table 11.

As the assumed sliding surfaces are with great uncertainty, so the safety coefficients obtained from the sliding surfaces may have great variations. Among the calculated 
TABLE 8: Stability calculation for southern slope (case 1: sliding surface of soft layer).

\begin{tabular}{|c|c|c|c|c|c|c|c|}
\hline $\begin{array}{l}\text { No. of } \\
\text { sliding } \\
\text { blocks }\end{array}$ & $\begin{array}{c}\text { Length of } \\
\text { sliding section } \\
L_{i}(\mathrm{~m})\end{array}$ & $\begin{array}{c}\text { Cohesion } C_{i} \\
(\mathrm{kPa})\end{array}$ & $\begin{array}{c}\text { Internal } \\
\text { friction angle } \\
\psi_{i}\left({ }^{\circ}\right)\end{array}$ & $\begin{array}{c}\text { Inclination of } \\
\text { sliding surface } \alpha_{i}\left({ }^{\circ}\right)\end{array}$ & $\begin{array}{c}\text { Self-weight of } \\
\text { sliding body } W_{i^{\prime}} \\
(\mathrm{kN})\end{array}$ & $\begin{array}{c}\text { Stability } \\
\text { coefficient } K_{s}\end{array}$ & $\begin{array}{l}\text { Residual sliding } \\
\text { force } E_{i}(\mathrm{kN})\end{array}$ \\
\hline 1 & 50.00 & 130.0 & 18.00 & 67.00 & $9,923.20$ & 1.97 & 5,195 \\
\hline 2 & 40.00 & 130.0 & 18.00 & 59.00 & $25,567.80$ & 1.97 & 22,130 \\
\hline 3 & 23.60 & 130.0 & 18.00 & 53.00 & $26,397.00$ & 1.97 & 38,531 \\
\hline 4 & 33.79 & 130.0 & 18.00 & 42.00 & $52,607.00$ & 1.97 & 63,134 \\
\hline 5 & 20.00 & 130.0 & 18.00 & 7.00 & $43,800.56$ & 1.97 & 42,591 \\
\hline 6 & 20.00 & 130.0 & 18.00 & 6.00 & $42,567.02$ & 1.97 & 38,610 \\
\hline 7 & 20.00 & 130.0 & 18.00 & 6.00 & $39,761.90$ & 1.97 & 34,924 \\
\hline 8 & 20.00 & 130.0 & 18.00 & 6.00 & $36,404.34$ & 1.97 & 31,438 \\
\hline 9 & 20.00 & 130.0 & 18.00 & 5.00 & $33,219.38$ & 1.97 & 27,460 \\
\hline 10 & 20.00 & 130.0 & 18.00 & 5.00 & $30,715.70$ & 1.97 & 23,771 \\
\hline 11 & 20.00 & 130.0 & 18.00 & 5.00 & $25,617.00$ & 1.97 & 20,474 \\
\hline 12 & 20.00 & 130.0 & 18.00 & 3.00 & $23,598.92$ & 1.97 & 16,372 \\
\hline 13 & 20.00 & 130.0 & 18.00 & 2.00 & $23,366.98$ & 1.97 & 11,967 \\
\hline 14 & 20.00 & 130.0 & 18.00 & 2.00 & $16,503.06$ & 1.97 & 8,503 \\
\hline 15 & 67.06 & 130.0 & 18.00 & 2.00 & $32,984.00$ & 1.97 & -208 \\
\hline
\end{tabular}

TABLE 9: Stability calculation for southern slope (case 2a: fracturing surface of $6 \#$ coal seam).

\begin{tabular}{|c|c|c|c|c|c|c|c|}
\hline $\begin{array}{l}\text { No. of } \\
\text { sliding } \\
\text { blocks }\end{array}$ & $\begin{array}{c}\text { Length of } \\
\text { sliding section } \\
L_{i}(\mathrm{~m})\end{array}$ & $\begin{array}{c}\text { Cohesion } C_{i} \\
(\mathrm{kPa})\end{array}$ & $\begin{array}{c}\text { Internal } \\
\text { friction angle } \\
\psi_{i}\left({ }^{\circ}\right)\end{array}$ & $\begin{array}{c}\text { Inclination of } \\
\text { sliding surface } \alpha_{i}\left({ }^{\circ}\right)\end{array}$ & $\begin{array}{c}\text { Self-weight of } \\
\text { sliding body } W_{i^{\prime}} \\
(\mathrm{kN})\end{array}$ & $\begin{array}{c}\text { Stability } \\
\text { coefficient } K_{s}\end{array}$ & $\begin{array}{l}\text { Residual sliding } \\
\text { force } E_{i}(\mathrm{kN})\end{array}$ \\
\hline 1 & 90.28 & 0.00 & 27.00 & 59.00 & $4,104.68$ & 1.63 & 2,854 \\
\hline 2 & 52.31 & 0.00 & 27.00 & 42.00 & $69,059.38$ & 1.63 & 32,534 \\
\hline 3 & 29.20 & 0.00 & 27.00 & 34.00 & $59,580.81$ & 1.63 & 48,575 \\
\hline 4 & 43.27 & 0.00 & 27.00 & 45.00 & $86,640.25$ & 1.63 & 92,593 \\
\hline 5 & 46.26 & 0.00 & 27.00 & 54.00 & $92,356.5$ & 1.63 & 153,653 \\
\hline 6 & 65.18 & 0.00 & 27.00 & 38.00 & $196,023.8$ & 1.63 & 206,480 \\
\hline 7 & 72.78 & 0.00 & 27.00 & 33.00 & $314,633.5$ & 1.63 & 288,402 \\
\hline 8 & 76.80 & 0.00 & 27.00 & 32.00 & $361,499.1$ & 1.63 & 381,918 \\
\hline 9 & 19.02 & 0.00 & 27.00 & 29.00 & $94,074.96$ & 1.63 & 394,838 \\
\hline 10 & 73.86 & 0.00 & 27.00 & 29.00 & 321,295 & 1.63 & 462,220 \\
\hline 11 & 64.41 & 0.00 & 27.00 & 2.00 & $285,943.6$ & 1.63 & 265,940 \\
\hline 12 & 74.53 & 0.00 & 27.00 & 2.00 & $286,016.5$ & 1.63 & 186,018 \\
\hline 13 & 91.41 & 0.00 & 27.00 & 2.00 & $278,881.9$ & 1.63 & 108,090 \\
\hline 14 & 94.42 & 0.00 & 27.00 & 2.00 & $204,797.4$ & 1.63 & 50,862 \\
\hline 15 & 132.70 & 0.00 & 27.00 & 2.00 & $174,479.5$ & 1.63 & 2,108 \\
\hline
\end{tabular}

TABLE 10: Stability calculation for southern slope (case $2 \mathrm{~b}$ : sliding surface of $6 \#$ coal seam).

\begin{tabular}{|c|c|c|c|c|c|c|c|}
\hline $\begin{array}{l}\text { No. of } \\
\text { sliding } \\
\text { blocks }\end{array}$ & $\begin{array}{c}\text { Length of } \\
\text { sliding section } \\
L_{i}(\mathrm{~m})\end{array}$ & $\begin{array}{c}\text { Cohesion } C_{i} \\
(\mathrm{kPa})\end{array}$ & $\begin{array}{c}\text { Internal } \\
\text { friction angle } \\
\psi_{i}\left({ }^{\circ}\right)\end{array}$ & $\begin{array}{c}\text { Inclination of } \\
\text { sliding surface } \alpha_{i}\left({ }^{\circ}\right)\end{array}$ & $\begin{array}{c}\text { Self-weight of } \\
\text { sliding body } W_{i^{\prime}} \\
(\mathrm{kN})\end{array}$ & $\begin{array}{c}\text { Stability } \\
\text { coefficient } K_{s}\end{array}$ & $\begin{array}{l}\text { Residual sliding } \\
\text { force } E_{i}(\mathrm{kN})\end{array}$ \\
\hline 1 & 90.28 & 0.00 & 27.00 & 59.00 & $4,264.60$ & 1.62 & 2,965 \\
\hline 2 & 52.31 & 0.00 & 27.00 & 42.00 & $71,750.00$ & 1.62 & 33,802 \\
\hline 3 & 29.20 & 0.00 & 27.00 & 34.00 & $61,902.14$ & 1.62 & 50,468 \\
\hline 4 & 43.27 & 0.00 & 27.00 & 45.00 & $90,015.84$ & 1.62 & 96,201 \\
\hline 5 & 46.26 & 0.00 & 27.00 & 54.00 & $95,954.81$ & 1.62 & 159,639 \\
\hline 6 & 65.18 & 0.00 & 27.00 & 38.00 & $203,661.12$ & 1.62 & 214,525 \\
\hline 7 & 72.78 & 0.00 & 27.00 & 33.00 & $326,891.96$ & 1.62 & 299,638 \\
\hline 8 & 76.80 & 0.00 & 27.00 & 32.00 & $375,583.44$ & 1.62 & 396,798 \\
\hline 9 & 19.02 & 0.00 & 27.00 & 29.00 & $97,740.22$ & 1.62 & 410,221 \\
\hline 10 & 73.86 & 0.00 & 27.00 & 29.00 & $333,812.99$ & 1.62 & 480,229 \\
\hline 11 & 64.41 & 0.00 & 27.00 & 2.00 & $297,084.23$ & 1.62 & 276,301 \\
\hline 12 & 74.53 & 0.00 & 27.00 & 2.00 & $297,160.01$ & 1.62 & 193,265 \\
\hline 13 & 91.41 & 0.00 & 27.00 & 2.00 & $289,747.47$ & 1.62 & 112,301 \\
\hline 14 & 94.42 & 0.00 & 27.00 & 2.00 & $212,776.48$ & 1.62 & 52,844 \\
\hline 15 & 132.70 & 0.00 & 27.00 & 2.00 & $181,277.42$ & 1.62 & 2,190 \\
\hline
\end{tabular}


TABLE 11: Stability calculation results of the sectional sliding slope.

\begin{tabular}{lccc}
\hline Case & Load combination & Transfer coefficient method & Safety coefficient \\
\hline 1 & Self-weight + sliding surface of coalbed no. 4 & 1.97 & 1.5 \\
$2 \mathrm{a}$ & Self-weight + fracturing surface of coalbed no. 6 & 1.63 & 1.5 \\
$\mathrm{2b}$ & Self-weight + sliding surface of coalbed no. 6 & 1.62 & 1.5 \\
\hline
\end{tabular}

safety coefficients, the minimum value is the most reasonable one that approximates to the solution for slope stability evaluation, and the related failure surface is the most dangerous sliding surface for slope. The calculated stability coefficients in the two cases range from 1.62 to 1.97 , which meet the requirements of the Design Code for Open-pit Mine of Coal Industry GB50197-2015. In the situation with hydraulic fractures, the slope stability coefficient decreases at the location where fault surface is exposed by mining of $6 \#$ coal seam, whereas the impact of CBM well fracturing on the overall slope stability is small.

\section{Conclusion}

(1) The CBM well fracturing barely imposed any effect on slope stability before the open-pit coal mining. In situations with and without CBM well fracturing, vertical stress distributions in the toe, top, and interior of slope have no obvious difference. There is just some extent of vertical stress increase around the fractures within the interior of slope.

(2) The presence of hydraulic fractures has little effect on the overall displacement of slope during coal mining, and there is no obvious difference between the slope stability during coal mining and the slope stability impacted by fracturing. Large displacement occurs on the top edge and central of slope, indicating a tendency for collapsing in these locations.

(3) Finally, according to the analyses of limit equilibrium method and numerical simulation, the impact of CBM well fracturing is less. Therefore, more attentions should be paid to the ways of excavation and sloping during coal mining, avoiding slope instability caused by excavation.

\section{Data Availability}

The data used to support the findings of this study are included within the article.

\section{Conflicts of Interest}

The authors have no conflicts of interest.

\section{Acknowledgments}

The authors would like to thank the general program "Research on Response Mechanism and Output Hydrodynamic Model of Coalbed Water Based on Efficient Drainage of Coalbed Methane" (41872179) funded by National
Natural Science Foundation of China; major science and technology program of the China National Petroleum Corporation "Research on Production Law and Technical Policy of Coalbed Methane Reservoir" (2017E-1405); and the Natural Science Foundation of Hebei Province's "Study on Reservoir Characteristics and Percolation Mechanism under the Coupling Condition of High Temperature and High Pressure of Deep Coalbed Methane" (D2019508167).

\section{References}

[1] C. Jia, M. Zheng, and Y. Zhang, "Unconventional hydrocarbon resources in China and prospect of exploration and development," Petroleun Exploration and Development, vol. 39, no. 2, pp. 129-136, 2012.

[2] C. Zou, G. Zhang, Z. Yang et al., "Geological concepts, characteristics, resource potential and key techniques of unconventional hydrocarbon: on unconventional petroleum geology," Petroleum Exploration and Development, vol. 40, no. 4, pp. 385-399, 2013.

[3] Y. Song, L. I. Zhuo, Z. Jiang et al., "Progress and development trend of geological research on unconventional oil and gas," Petroleum Exploration and Development, vol. 44, no. 4, pp. 638-648, 2017.

[4] National Energy Administration, $13^{\text {th }}$ Five-Year Plan for Development and Utilization of Coal-bed Methane: Coal Mine Gas, National Energy Administration, Beijing, China, 2016.

[5] X. Zhang and Y. Zheng, "Analysis of the coordinated development of coal bed methane and coal resources," Coal Geology \& Exploration, vol. 37, no. 3, pp. 19-26, 2009.

[6] Q. Zhao, X. Kong, and Q. Zhao, "Coalbed methane accumulation conditions and production characteristics," Oil \& Gas Geology, vol. 33, no. 4, pp. 552-560, 2012.

[7] W. Wang, W. Yang, and F. Tang, "Preliminary analysis on stress state before of and after fracturing of coal seam and sandstone," Coal Geology \& Exploration, vol. 29, no. 1, pp. 31-33, 2001.

[8] Y. Wang, Y. Lu, Y. Li et al., "Progress and application of hydraulic fracturing technology in unconventional reservoir," Acta Petrolei Sinica, vol. 33, no. 1, pp. 149-158, 2012.

[9] L. Zhou, Coalbed Well Hydraulic Fracturing's Influences on Coal Mining: A Case Study of SiHe Coal Mine, China University of Mining and Technology, Xuzhou, China, 2014.

[10] L. I. Zhi and D. Pan, "Analysis of mutual influence between goaf and open pit slope," Mining Research and Development, vol. 34, no. 6, pp. 37-40, 2014.

[11] G. Ding, "Stability and landslide risk analysis of slope above goaf," The Chinese Journal of Geological Hazard and Control, vol. 23, no. 2, pp. 38-43, 2012.

[12] X. Liu, "Analysis of slope stability affected by goaf," Opencast Mining Technology, vol. 31, no. 1, pp. 32-35, 2016.

[13] S. Wang, "Analysis on the effect of slope part cracks on slope stability in shengli east no. 2 open-pit mine," Opencast Mining Technology, vol. 35, no. 1, pp. 83-85, 2020. 
[14] S. Chen, R. Wu, L. Han et al., "Influence of end slope with a tensile fracture on slope stability in open-pit coal mine," Safety in Coal Mines, vol. 50, no. 11, pp. 228-231, 2019.

[15] F. Sun, W. Li, Q. Sun et al., "Low-rank coalbed methane exploration in jiergalangtu sag, erlian basin," Acta Petrolei Sinica, vol. 5, pp. 5-12, 2017.

[16] Q. Sun, B. Sun, F. Sun et al., "Accumulation and geological controls of low-rank coalbed methane in southeastern junggar basin," Geological Journal of China Universities, vol. 3, pp. 460-464, 2012.

[17] S. Wang, L. Shao, Q. Sun et al., "Sequence-palaeogeography and coal accumulation of the lower cretaceous saihantala formation in the bayanbaolige coalfield, erlian basin, inner Mongolia," Journal of Palaeogeography, vol. 20, no. 2, pp. 325-336, 2018.

[18] B. Gou, J. Guo, Y. Li et al., "Simulation analysis of fractureheight extension factor based on fracpropt software," Natural Gas Exploration \& Development, vol. 33, no. 1, pp. 54-57, 2010.

[19] F. Zhang, B. Damjanac, and S. Maxwell, "Investigating hydraulic fracturing complexity in naturally fractured rock masses using fully coupled multiscale numerical modeling," Rock Mechanics and Rock Engineering, vol. 52, no. 12, pp. 5137-5160, 2019.

[20] D. Wang, J. Jiang, S. Liu et al., "Research on relative slope stability criterion and its application in open-pit coal mines," China Safety Science Journal, vol. 28, no. 7, pp. 76-81, 2018.

[21] J. Tang, K. Wu, Y. Li, X. Hu, Q. Liu, and C. Ehlig-Economides, "Numerical investigation of the interactions between hydraulic fracture and bedding planes with non-orthogonal approach angle," Engineering Fracture Mechanics, vol. 200, pp. 1-16, 2018.

[22] Y. Li, M. Long, J. Tang, M. Chen, and X. Fu, "A hydraulic fracture height mathematical model considering the influence of plastic region at fracture tip," Petroleum Exploration and Development, vol. 47, no. 1, pp. 184-195, 2020. 